\title{
American Cockroach Antigen IgE Antibody Measurement
}

National Cancer Institute

\section{Source}

National Cancer Institute. American Cockroach Antigen IgE Antibody Measurement. NCI Thesaurus. Code C130136.

A measurement of the American cockroach (Periplaneta americana) antigen IgE antibody in a biological specimen. 